$14^{\text {th }}$ Conf. Agric. Develop. Res., Fac. of Agric., Ain Shams Univ., March, 2019, Cairo, Egypt

Special Issue, 27(1), 563 - 577, 2019

Website: http://strategy-plan.asu.edu.eg/AUJASCI/

\title{
DEVELOPMENT OF IN VITRO SOMACLONAL VARIATION FOR PELARGONIUM GRAVEOLENS L'HERIT, AIT
}

\author{
Rasha I.M. Hariedy ${ }^{1}$, Rashed ${ }^{2}$, M.A. and Mahassen ${ }^{1}$ M.A. Sidky
}

1. Medicinal and Aromatic Plant Research Dept., Horticulture Research Institute, ARC, Giza, Egypt.

2. Genetics Dept., Fac. of Agric., Ain Shams Univ., P.O. Box 68 Hadyek Shoubra11241, Cairo, Egypt

*Corresponding author: rashaibrahimhariedy@gmail.com

Received 14 October, 2018, $\quad$ Accepted 24 October, 2018

\begin{abstract}
In vitro somaclonal variation via callus is considered as one of the most effective tool for improvement of vegetative propagated crops. Different combinations of cytokinine (BA) and auxine (NAA) were used to induce somaclonal variation from leaf explants of the Egyptian geranium cultivar, Pelargonium graveolens L'Herit, Ait. El Qanater El khayria cv.8. Callus induction and regenerated shoots from callus were evaluated; 2.5 $\mathrm{mg} / \mathrm{L} \mathrm{BA}$ and $0.5 \mathrm{mg} / \mathrm{L} \mathrm{NAA}$ was the optimal for callus induction and number of regenerated shoots. The obtained plantlets were acclimatized under glasshouse conditions with $80 \%$ to $90 \%$ survival and were transferred to the open field. The evaluation of growth traits and oil analysis were done for the new 13 clones compared with the mother plant in randomized block design for two successive seasons. Characterization of these new clones for morphological traits and essential oil yield and quality demonstrated the induction of variability in negative and positive directions in some characteristics in comparison with the mother plant. Clone no.7 was the superior clone in herb 2264.7 \& $2357.3 \mathrm{~g} / \mathrm{plant}$ and oil yield 2.436 \& $3.065 \mathrm{ml} / \mathrm{plant}$ in first and second season, respectively, than the mother plant and other new clones with acceptable content of citronellol $25.63 \%$ and geraniol $26.52 \%$ as a parameter for volatile oil quality.

The genetic variation of the new geranium clones were tested using SRAP technique based on PCR, the polymorphism was detected using 16
\end{abstract}

pairs of SRAP primers in combinations as forward and reverse. The genetic differences between new clones and the mother plant were ascertained with SRAP primer pair (me2 em4); a unique profile for clone no.7 was detected in SRAP analysis. The similarity percentage varied between $66.7 \%$ to $100 \%$ homologies among the new clones and their mother plant. The presence of genetic variation between new clones and the mother plant proved that the calliclones were somaclonal mutants, and the geranium cultivar, El Qanater El khayria cv.8, was improved for high yield in herb and essential oil.

Keywords: Pelargonium graveolens L'Herit, Ait, In vitro somaclonal, SRAP technique

\section{INTRODUCTION}

Geranium; Pelargonium graveolens L'Herit, Ait. is one of the important medicinal and aromatic plants in Egypt, which belongs to family Geraniaceae, originated from South Africa (cape) and introduced into Egypt since 1930, (Guenther, 1961). Geranium, Pelargonium graveolens is cultivated for distillation its oil. Geranium oil is considered one of the most important essential oil that is for its rose like odor which is commercially used in high-grade soaps, cosmetics and perfumes (Gulati, 1960; Lawrence, 1984; Narayana et al 1986). Geranium is cultivated in many Egyptian governorates mainly Beni Swiaf as well as El-Gharbia, El-Qalubeya, ElFayoum and Giza. According to the Ministry of Agriculture (2015), the cultivated area reached to 
4837 feds, geranium productivity is tending to decrease, recording about 21.75 tons fresh herb/fed instead of 30-35 ton fresh herb/fed. However, this decrement which is due to some constraints including lack of new geranium varieties and cultivars of high productivity of herb and essential oil, Egyptian geranium essential oil still have a good quality and priority in the global market. The main constituents of geranium oil are citronellol, geraniol, isomenthone, citronellyl formate and geranyle formate (Weiss, 1997). The geranium oil quality is mainly determined by total alcohol content and the ratio of citronellol and geraniol (Rajeswara et al 1989). Egyptian oil have relatively low levels of citronellol and its esters, much higher levels of geraniol, geranyle esters and linalool when compared with the Chinese oil (Teisseire, 1987). Jalali - Heravi et al (2006) indicated that, Geranium oil production needs to be increased because geranium oil uses are expanding owing to its aromatic property and its biological activities.

Geranium plants are vegetativley propagated through stem cuttings since conventional breeding to improve this important crop is very much hampered due to its high degree of male and female sterility (Kubba and Tilney - Basset, 1981). The development of suitable cultivars to meet the production challenges is difficult due to narrow genetic base and sterility of geranium (Gupta et al 2002). Some studies are going to use tissue culture technique to produce new geranium clones via somaclonal variation which offers an opportunity to discover the natural variability for new product development (Evans and Sharp, 1986). The somaclonal variation has proved to be an effective tool to release variability without the deleterious genetic changes which happened through the whole-plant regeneration process (Dunbar, 1997, Evans, 1989 and Veilleux \& Johnson, 1998). Calliclones of scented Pelargonium spp showed high variability comparing to mother plant (Skirvin and Janick, 1976a) and (Gauri et al 2000) obtained calliclones from Pelargonium graveolens Indian cultivar Hemanti which some of them resembled mother plant and others different in several herb related agronomic characteristics. Some of studies led to develop a somaclonal variant, called 'Velvet rose' (Skirvin and Janick, 1976b) and 'B22' (Gupta et al 2002) as new cultivar.

The SRAP (Sequence-related amplified polymorphism) is a novel, simple and reliable marker based on PCR developed by $\mathbf{L i}$ and Quiros (2001), and detects polymorphisms in coding sequences, which are more conserved between cul- tivars and have a relatively low mutation rate (Korir et al 2012). Lin et al (2003), Zhao et al (2009) and Uzun et al (2009) indicated that, SRAP marker is an effective analysis for genetic diversity, variety/cultivar identification and phylogenetic studies. Budak et al (2004) reported that SRAP marker with rich polymorphism could be used to distinguish cultivars with close genetic relationship, and also Zaefizadeh and Goliev (2009) indicated that SRAP markers give information more related to morphological variability and evolutionary history of morphotypes than that by AFLP markers. It is appeared that SRAP successfully utilized in other crops such as Brassica, sesame, citrus and radish (Li and Quiros, 2001, Liu et al 2008, Amar et al 2011 and Zhang et al 2011).

So; the present work aimed to generate new geranium clones with high herb and essential oil overall production using tissue culture technique. In addition to detect the somaclonal variation and the related genetic markers for further selection and thus, genetic improvement of the cultivated geranium in Egypt El Qanater El khayria cv.8.

\section{MATERIALS AND METHODS}

This study investigated the possibilities of improving geranium (Pelargonium graveolens L'Herit, Ait.) via somaclonal variation aiming to produce new clones have good characteristics in herb and essential oil. It was carried out in plant tissue culture laboratory, Dokki, Giza and in the Experimental Farm of Medicinal and Aromatic Plants, El Qanater El kharyia of Horticulture Research Institute (HRI), Agriculture Research center (ARC). The molecular study was carried out in Molecular biology laboratory, Genetics Department of Faculty of Agriculture, Ain Shams University, Egypt during the period from $2015-2018$.

\section{Plant material}

Egyptian geranium cultivar namely; El Qanater El khayria cv.8 was used in this study as a mother plant, which grown in the Experimental Farm of Medicinal and Aromatic Plants in El Qanater El kharyia; HRI and characterized by high yield of herb and essential oil (Harridy et al 1998).

\section{Methods}

Somaclonal variation induction via callus from leaf explants

Young leaves were collected from the terminal tip of in vivo geranium mother plant cv.8. The leaf 
explants were washed under running tap water and sterilized by immersing in sodium hypochlorite $30 \%$ with two drops of tween 20 (emulsifier) for 30 minutes, then rinsed three times in a sterile distilled water. A $4.43 \mathrm{~g} / \mathrm{l} \mathrm{MS}$ medium (Murashige and Skoog, 1962) with $3 \%$ sucrose and $8 \mathrm{~g} / \mathrm{l}$ agar as solidifying agent was supplemented by different concentrations between growth regulators, benzyle adenine (BA) as cytokinins (0.0 1.5 ، 2.5 ، 3.5 or 4.5) $\mathrm{mg} /$ and naphthaline acetic acid (NAA) as auxins $(0.0$ ، 0.5 ، 1.5 or 2.5$) \mathrm{mg} \Lambda$. $\mathrm{pH}$ was adjusted to 5.8 by $1 \mathrm{M}$ of $\mathrm{NaOH}$ and $\mathrm{HCL}$. The medium was autoclaved at $121^{\circ} \mathrm{C}$ for 20 minutes. Three explants / jar were cultured and incubated for 6-8 weeks at $25 \pm 2^{\circ} \mathrm{C}$ with $16 / 8 \mathrm{hr}$ photoperiod to induce callus formation. Data were recorded as frequency percentage of callus formation, callus density, callus texture (friable or compact), callus color, number of regenerated shoot on callus/leaf explant and cluster weight $(\mathrm{gm})$. Statistical analyses were done and the means of the studied characters were compared to the control using LSD according to Snedecor (1980).

\section{In vitro micropropagation for geranium regen- erated shoots}

The produced indirect shoots which formed via callus from leaf explants were subcultured on MS medium supplemented with the suitable growth regulators (0.05 $\mathrm{BA} \mathrm{mg} / \mathrm{l}$ with $0.05 \mathrm{NAA} \mathrm{mg} / \mathrm{l}$ ) to encourage shooting growth, then the produced plantlets were subcultured on the suitable medium for rooting growth (half strength MS with 0.1 NAA $\mathrm{mg} / \mathrm{l})$ as established in preliminary steps according to Gupta et al (2002) for rooting.

\section{Acclimatization and transfer to open field}

The acclimatization of the produced plantlets was done with all good conditions. The plantlets kept to grow for 4-6 weeks, and they were transferred to the open field in the Experimental farm of Medicinal and Aromatic Plants Research Department in EI Qanater El Khayria. The healthy-looking survived plants were codely numbered from 1 to 13 and were considered as new cultivars under evaluation) in a comparative with the mother plant number 14. All good agriculture practices were done till these new geranium plants attained suitable growth and produced mature cuttings in order to use them in the present study.

\section{Evaluation in the open field}

Cuttings were prepared from the 13 coded plants and from the mother plant no.14, and were planted at 10 November during two successive seasons of 2015 / 2016 and 2016 / 2017. The Experiment was designed in complete randomized blocks with three replicates, plants were harvested twice, the first one was conducted at the end of May (when more than $50 \%$ of plants were flowered) and the second one at the middle of October in the two seasons. Data were taken on growth characters in term of plant height, branches number, fresh and dry weights for each cultivar in two cuts. Also, oil percentage (fresh and dry weight basis) was determined by hydro-distillation according to British pharmacopeia (B.P.) (1963). And oil samples were GLC analyzed according to Egyptian pharmacopeia (E.P.) (2005) to evaluate oil composition. Statistical analyses were done and the means of the clones were compared to the mother plant (control) according to Duncan (1995).

Test for genetic variation using SRAP technique

Sequence-related amplified polymorphism (SRAP) technique according to Li and Quaros (2001) was used for identification of genetic variation and DNA fingerprint for new clones of geranium in comparison with the mother plant.

For SRAP- PCR analysis, total genomic DNA was extracted from young leaves for the14 geranium plants according to Cetyl Trimethyl Ammonium Bromide (CTAB) extraction method (SaghaiMaroof et al 1984). The extraction buffer consisted of Tris buffer 100 (mM, pH 8.0), Ethylene Diamine Tetra Acetic acid Di-sodium salt (EDTA), $25 \mathrm{mM}$, $\mathrm{pH}$ 8.0) $\mathrm{NaCl}(1.4 \mathrm{M}), 2.5 \%$ CTAB (V:W) $\mathrm{pH} 8.0$, $1 \%$ polyvinyl pyrrolidone (PVP- 40 ) and $2 \% \beta$ mercaptoethanol (v:v). All were adjusted to $\mathrm{pH} 5.0$ with $\mathrm{HCL}$ and volume was adjusted to $100 \mathrm{ml}$ with $\mathrm{H}_{2} \mathrm{O}$.

DNA quality was confirmed by electrophoresis in $1 \%$ agarose gel, presence of a highly resolved high molecular weight band indicates good quality DNA. DNA quantity was estimated for the 14 samples by using Quantus ${ }^{\mathrm{TM}}$ Fluorometer operating manual.

SRAP primer pairs in Table (1) and a16 available combinations in Table (2) used as forward and reverse primers, SRAP protocol and SRAP primer sequences followed the method established by $\mathbf{L i}$ and Quiros (2001). 
The primer combinations were tested on only two samples of the DNA from the 14 plants as a trials aiming to test the primer pairs combinations performance with the DNA samples, which gave a polymorphism. The primer pairs were selected from the primers combinations according to their performance and polymorphism and were done on the 13 samples of new clones in a comparison with the mother plant no.14 for testing genetic variation and genetic relationship.

\section{Primer codes and sequences}

Table 1.The available SRAP primer pairs.

\begin{tabular}{|c|c|c|c|}
\hline Primer code & Primer sequence & Primer code & Primer sequence \\
\hline me1 & 5`TGAGTCCAAACCGGATA-3` & em1 & 5`-GACTGCGTACGAATTAAT-3` \\
\hline me2 & 5`-TGAGTCCAAACCGGAGC-3` & em2 & 5`-GACTGCGTACGAATTTGC-3` \\
\hline me3 & 5`-TGAGTCCAAACCGGAAT-3` & em3 & 5`-GACTGCGTACGAATTGAC-3` \\
\hline me4 & 5`-TGAGTCCAAACCGGACC-3` & em4 & 5'-GACTGCGTACGAATTTGA-3` \\
\hline
\end{tabular}

Table 2. The combinations of SRAP primer pairs

\begin{tabular}{|c|c|c|c|c|}
\hline $\begin{array}{c}\text { Primer } \\
\text { combination }\end{array}$ & me1 & me2 & me3 & me4 \\
\hline em1 & PC1 & PC2 & PC3 & PC4 \\
\hline em2 & PC5 & PC6 & PC7 & PC8 \\
\hline em3 & PC9 & PC10 & PC11 & PC12 \\
\hline em4 & PC13 & PC14 & PC15 & PC16 \\
\hline
\end{tabular}

PCR (polymerase chain reaction) was carried out in $25 \mu \mathrm{l}$ reaction volume tubes, containing 4.0 $\mu$ l Buffer (5X), $2.0 \mu \mathrm{l}$ Template (25 ng of plant genomic DNA), $2.0 \mu \mathrm{l} \mathrm{MgCl} 2$ (25 mM), $0.4 \mu \mathrm{l}$ dNTPs (2.5 mM) $1+1 \mu$ l Primer (10 pmol), $0.2 \mu \mathrm{l} \mathrm{Tag} \mathrm{DNA}$ polymerase and $9.4 \mu \mathrm{H} 2 \mathrm{O}$ (d.w). Amplification was carried out in DNA thermal cycler (techne 512 ), The first five cycles were run at $94^{\circ} \mathrm{C}, 1 \mathrm{~min}$, $35^{\circ} \mathrm{C}, 1 \mathrm{~min}$, and $72^{\circ} \mathrm{C}, 1 \mathrm{~min}$, for denaturing, annealing and extension, respectively. Then the annealing temperature is raised to $50^{\circ} \mathrm{C}$ for another 35 cycles then at $72^{\circ} \mathrm{C}$ for $7 \mathrm{~min}$.

The PCR products were loaded in $2 \%$ agarose gel, dissolved in a $50 \mathrm{~mL}$ of $1 \times$ TBE buffer and were electrophorased. The separation was performed in Pharmacia unit $(20 \mathrm{~cm} \times 20 \mathrm{~cm})$ and the voltage was adjusted to $80 \mathrm{~V}$. The gels were photographed after the run was ended using Bio-Rad Gel Doc 2000 apparatus. All the gels were analyzed using gel analyzer program, and the different fragment sizes were scored in a binary data ( 1 if the band is present and 0 if it is absent). Bands with the same size were scored as a line according to the size of the DNA ladder (100 bp).

\section{RESULTS AND DISCUSSION}

\section{Induction of somaclonal variation via callus from leaf explants}

The present study demonstrated that, the leaf explants of geranium, Pelargonium graveolens El Qunater El Khayria cv.8 was highly responsive to in vitro callus induction and formation. Dunbar and Stephen (1989) earlier reported this result in some Pelargonium species and Lakshmana (1994) in some cultivars of P.graveolens. These results showed that all concentrations of solo BA and solo NAA were not effective to callus induction as shown in Table (3). All combinations of BA and NAA used for callus induction were found to be effective at the tested concentrations. Therefore, regenerated shoots were directly developed from callus on leaf explants after 4-6 weeks of culturing as shown in Table (3). There was a $100 \%$ frequency of callus formation with density of callus varied from $33 \%$ to $84 \%$ of the leaf explants at various combinations, while the friable formed callus, semi friable, green and white creamy in color was highly regenerated to shoots. Lower amount of compact white creamy callus was formed on the two media at the highest tested concentration of BA ( 3.5 \& 4.5 $\mathrm{mg} / \mathrm{l})$ and NAA $(2.5 \mathrm{mg} / \mathrm{l})$ without formed shoots on callus as shown in Table (3). 
Table 3. The effect of BA in combination with NAA on callus and shoots induction

\begin{tabular}{|c|c|c|c|c|c|}
\hline $\begin{array}{c}\text { BA } \\
\text { NAA }\end{array}$ & 0.0 & 1.5 & 2.5 & 3.5 & 4.5 \\
\hline 0.0 & - & - & - & - & - \\
\hline 0.5 & - & $\begin{array}{c}\text { Callus } \\
+ \\
\text { shoots }\end{array}$ & $\begin{array}{c}\text { Callus } \\
+ \\
\text { more } \\
\text { shoots }\end{array}$ & $\begin{array}{c}\text { Callus } \\
+ \\
\text { shoots }\end{array}$ & $\begin{array}{c}\text { Callus } \\
+ \\
\text { Shoots }\end{array}$ \\
\hline 1.5 & - & $\begin{array}{c}\text { Callus } \\
+ \\
\text { shoots }\end{array}$ & $\begin{array}{c}\text { Callus } \\
+ \\
\text { shoots }\end{array}$ & $\begin{array}{c}\text { Callus } \\
+ \\
\text { shoots }\end{array}$ & $\begin{array}{c}\text { Callus } \\
+ \\
\text { Shoots }\end{array}$ \\
\hline 2.5 & - & $\begin{array}{c}\text { Callus } \\
+ \\
\text { shoots }\end{array}$ & $\begin{array}{c}\text { Callus } \\
+ \\
\text { shoots }\end{array}$ & $\begin{array}{l}\text { compact } \\
\text { callus }\end{array}$ & $\begin{array}{c}\text { compact } \\
\text { Callus }\end{array}$ \\
\hline
\end{tabular}

The shoot regeneration response could be recorded at all combinations levels among BA and NAA. As shown in Table (4) and Fig. (1), the highest number of regenerated shoots was noticed on media containing $0.5 \mathrm{mg}$ NAA in combination with various levels of $\mathrm{BA}(1.5,2.5$ and $3.5 \mathrm{mg} / \mathrm{l})$. A maximum average for number of regenerated shoots (33.33 shoot/callus) formed on leaf explants was recorded on medium containing $2.5 \mathrm{mg} / \mathrm{l} \mathrm{BA}$ and $0.5 \mathrm{mg} / \mathrm{l} \mathrm{NAA}$ with high percent $70 \%$ of callus den- sity. The lowest number of regenerated shoots was recorded on media containing $2.5 \mathrm{mg} / \mathrm{l} \mathrm{BA}$ and 1.5 $\mathrm{mg} / \mathrm{N}$ NA. However, this combination showed a $64 \%$ of callus density on leaf explants.

It was observed that, the reduction of the concentration levels of NAA led to decrease the number of regenerated shoots from callus per leaf explants at various levels of BA. The increasing on the number of regenerated shoots may develop variants between these regenerated shoots from callus Table (4) and Fig. (1). These observations were similar to those reported by Gupta et al (2002). In contrast, increased the levels of NAA to 1.5 and $2.5 \mathrm{mg} / \mathrm{l}$ led to reduction in the average of regenerated shoots number at all levels of BA as shown in Table (4).

The healthy shoots were formed on media containing $2.5 \mathrm{mg} / \mathrm{l} \mathrm{BA}$ and $0.5 \mathrm{mg} / \mathrm{l} \mathrm{NAA}$ with the maximum number of regenerated shoots from callus on leaf explants and the other one containing the same level of BA and NAA but with low average of regenerated shoots. The regenerated shoots formed on media containing $4.5 \mathrm{mg} / \mathrm{l} \mathrm{BA}$ in combination with $1.5 \mathrm{mg} / \mathrm{l} \mathrm{NAA}$ and $1.5 \mathrm{mg} / \mathrm{l} \mathrm{BA}$ with $2.5 \mathrm{mg} / \mathrm{l}$ NAA were malformed and vitrified.

Table 4. Growth characteristics of callus and regenerated shoots grown in media containing different BA and NAA combinations

\begin{tabular}{|c|c|c|c|c|c|c|c|c|}
\hline \multicolumn{3}{|c|}{ combinations } & \multicolumn{5}{c|}{ Growth characteristics of callus and regenerated shoots } \\
\hline No & $\begin{array}{c}\text { BA } \\
\text { mg/l }\end{array}$ & $\begin{array}{c}\text { NAA } \\
\text { mg/l }\end{array}$ & $\begin{array}{c}\text { \% frequency } \\
\text { of callus for- } \\
\text { mation }\end{array}$ & $\begin{array}{c}\% \\
\text { density } \\
\text { of callus }\end{array}$ & $\begin{array}{c}\text { Callus } \\
\text { texture }\end{array}$ & $\begin{array}{c}\text { Callus } \\
\text { color }\end{array}$ & $\begin{array}{c}\text { Number of } \\
\text { regenerated } \\
\text { shoots }\end{array}$ & $\begin{array}{c}\text { Cluster } \\
\text { weight } \\
\text { (gm) }\end{array}$ \\
\hline 1 & 1.5 & 0.5 & 100 & 0.68 & $\mathrm{f}$ & $\mathrm{w} / \mathrm{cr}, \mathrm{g}$ & 20.0 & 7.89 \\
2 & 2.5 & 0.5 & 100 & 0.70 & $\mathrm{f}$ & $\mathrm{g} / \mathrm{cr}$ & 33.33 & 9.57 \\
3 & 3.5 & 0.5 & 100 & 0.70 & $\mathrm{f} \& \mathrm{semi}$ & $\mathrm{g}, \mathrm{cr}$ & 20.33 & 7.89 \\
4 & 4.5 & 0.5 & 100 & 0.36 & $\mathrm{f}$ & $\mathrm{cr}$ & 13.33 & 4.68 \\
5 & 1.5 & 1.5 & 100 & 0.63 & $\mathrm{c}$ & $\mathrm{g}, \mathrm{cr}$ & 9.0 & 6.64 \\
6 & 2.5 & 1.5 & 100 & 0.33 & $\mathrm{f} \& \mathrm{semi}$ & $\mathrm{cr}$ & 7.66 & 5.29 \\
7 & 3.5 & 1.5 & 100 & 0.51 & $\mathrm{f}$ & $\mathrm{g}, \mathrm{cr}$ & 11.0 & 4.77 \\
8 & 4.5 & 1.5 & 100 & 0.67 & $\mathrm{semi}$ & $\mathrm{cr}, \mathrm{g}$ & 13.0 & 9.00 \\
9 & 1.5 & 2.5 & 100 & 0.64 & $\mathrm{f} \& \mathrm{semi}$ & $\mathrm{cr}, \mathrm{g}$ & 5.0 & 9.32 \\
10 & 2.5 & 2.5 & 100 & 0.50 & $\mathrm{f} \& \mathrm{semi}$ & $\mathrm{cr} / \mathrm{g}$ & 11.0 & 9.87 \\
11 & 3.5 & 2.5 & 100 & 0.84 & $\mathrm{c}$ & $\mathrm{w} / \mathrm{cr}$ & 0.0 & 6.53 \\
12 & 4.5 & 2.5 & 100 & 0.51 & $\mathrm{c}$ & $\mathrm{cr}$ & 0.0 & 8.28 \\
\hline
\end{tabular}

f: friable texture c: compact texture semi: friable compact texture

w: white color g: green color creamy color

LSD at 0.05 : least significant differences with $95 \%$ level of confidence. 


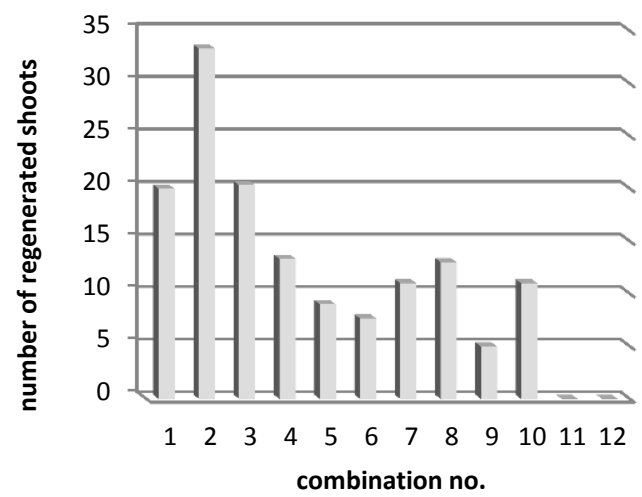

Fig. 1. Effect of BA \& NAA combinations shoots on callus from leaves explants.

1 to 12 combination number as (presented in Table 4)

It was demonstrated that, the different levels of $B A$ on media were effective for shoot regeneration from callus except those two high levels of BA (3.5 and $4.5 \mathrm{mg} / \mathrm{l}$ ) which showed ineffective responses to shoot regeneration at the same level of NAA (2.5 mg/l), while the lower levels of BA (1.5 and 2.5 $\mathrm{mg} / \mathrm{l})$ showed effective responses in shoot regeneration from callus but with low average in the number of shoots as shown in Table (4) and Fig. (1). These results were confirmed by Gupta et al (2002) when indicated that different levels of cytokinins were effective for in vitro regenerated shoots from callus of some geranium species and by Qureshi and Saxena (1992) indicated in floricultural geranium that the combinations of BA with some auxines were effective for optimal shoot regeneration. Brown and Charlwood (1986) and Saxena et al (2000) also found that some other cytokinines (kinetin, zeatine and $2 \mathrm{iP}$ ) were effective for optimum level of regeneration response from callus cultures.

\section{Shooting and rooting growth for regenerated calliclones}

The in vitro regenerated shoots were subcultured on MS medium supplemented with $0.05 \mathrm{mg} / \mathrm{l}$ BA and $0.05 \mathrm{mg} / \mathrm{l}$ NAA to attain suitable shoot growth and multiplication in order to subculture them on the suitable medium for rooting growth. The formation of roots succeeded and suitable number of roots were formed on half strength of MS medium supplemented with $0.1 \mathrm{mg} / \mathrm{l}$ NAA according to Gupta et al (2002).

Plantlets with expanded leaves and well developed roots were acclimatized with records of $80 \%$ to $90 \%$ for survival. The healthy- looking plantlets were transferred to the open field. Thirteen individual plantlets of geranium calliclones were kept to attain suitable growth and produced mature cuttings in order to evaluate them in a comparative study with the mother plant under the field conditions.

\section{Evaluation of Geranium calliclones under open field conditions}

The new geranium clones under evaluation were compared with the mother plant by culturing their cuttings at the same time and in the same field. The evaluation of two cuts/year during two successive seasons included growth traits such as plant height, branches number and total fresh \& dry weights as well as oil analysis; oil percentage based on fresh weight, oil percentage based on dry weight, oil yield/plant and oil constituents.

\section{Growth traits}

It was clearly observed in Tables (5 and 6) for plant height trait all over the cloned production during the two seasons that clone no. 4 recorded the highest value followed by clone no. 7 then clone no.3, while clones no.11 and 12 had the lowest values compared with the mother plant (no.14). Branches number showed that clones no.7 and 4 attained the highest values followed by clones no.13 and 6 , while the lowest values for this trait were for clones no.9, 10, 11 and 12. Concerning the fresh and dry weight traits of geranium clones, clone no.7 recorded the highest significant differences in total fresh weight of herb for the first (2264.7 $\mathrm{gm})$ and second (2357.3 gm) seasons. While the lowest total fresh weights were for clones no.9 and no.11 Fig. (2). Also clone no.7 recorded the highest value in total dry weight as shown in the first $(626.6 \mathrm{gm})$ and second $(650.99 \mathrm{gm})$ seasons. 
Table 5. Growth traits of new geranium clones and their mother plant (no.14) during the first season

\begin{tabular}{|c|c|c|c|c|c|c|c|c|c|c|}
\hline \multirow{2}{*}{$\begin{array}{c}\text { Harvest } \\
\text { Clone } \\
\text { number }\end{array}$} & \multicolumn{4}{|c|}{ First cut } & \multicolumn{4}{|c|}{ Second cut } & \multicolumn{2}{|c|}{$\begin{array}{c}\text { Total fresh \&dry weights } \\
\text { of two cuts }\end{array}$} \\
\hline & $\begin{array}{l}\text { Plant } \\
\text { height } \\
\mathrm{cm} / \mathrm{p} .\end{array}$ & $\begin{array}{c}\text { Branches } \\
\text { no }\end{array}$ & $\begin{array}{c}\text { Fresh weight } \\
\mathrm{gm} / \mathrm{p} .\end{array}$ & $\begin{array}{c}\text { Dry weight } \\
\text { gm / p. }\end{array}$ & $\begin{array}{c}\text { Plant height } \\
\mathrm{Jcm} / \mathrm{p} .\end{array}$ & $\begin{array}{c}\text { Branches } \\
\text { no }\end{array}$ & $\begin{array}{l}\text { Fresh } \\
\text { weight } \\
\mathrm{gm} / \mathrm{p} .\end{array}$ & $\begin{array}{l}\text { Dry weight } \\
\mathrm{gm} / \mathrm{p} .\end{array}$ & $\begin{array}{c}\text { F.W. of the } \\
\text { two cuts } \\
\mathrm{gm} / \mathrm{p} .\end{array}$ & $\begin{array}{l}\text { D.W. of the } \\
\text { two cuts } \\
\mathrm{gm} / \mathrm{p} \text {. }\end{array}$ \\
\hline 1 & $68.8^{\mathrm{de}}$ & $15.1^{\mathrm{cd}}$ & $656.3^{f}$ & $157.52^{\mathrm{g}}$ & $80.6^{\text {def }}$ & $8.6^{\mathrm{c} \mathrm{de}}$ & $422.6^{f}$ & $103.98^{f}$ & 1078.9 & 261.5 \\
\hline 2 & $73.6^{\mathrm{od}}$ & $13.5^{\mathrm{de}}$ & $1075^{b}$ & $301^{b}$ & $83.6^{\mathrm{de}}$ & $10^{a b c d}$ & 517.6 ef & $141.01 \mathrm{e}$ & 1592.6 & 442.01 \\
\hline 3 & $83.3 \mathrm{ab}$ & $15.8^{\mathrm{bc}}$ & $1073.6^{\mathrm{b}}$ & $279.15^{c}$ & $83^{\mathrm{de}}$ & $7.6^{\mathrm{de}}$ & $749 c$ & $208.24^{b c}$ & 1822.6 & 487.39 \\
\hline 4 & $84.8^{a}$ & $16.1^{b c}$ & $1108^{a b}$ & $288^{\mathrm{bc}}$ & $118.6^{a}$ & $12^{\mathrm{ab}}$ & $1083.3^{a}$ & $291.2^{a}$ & 2191.3 & 579.28 \\
\hline 5 & 81.6 ab & 12.6 ef & $896.3^{d}$ & $233 \mathrm{e}$ & 96 bod & 9.3 bode & $825.3 \mathrm{bc}$ & $233.73^{b}$ & 1721.6 & 466.73 \\
\hline 6 & $77.6^{b c}$ & $15.3^{\mathrm{cd}}$ & $970.3^{c}$ & $252.28^{d}$ & 75.3 ef & $11^{\mathrm{abc}}$ & 766 bc & $206.51^{c}$ & 1736.3 & 458.79 \\
\hline 7 & 83.6 ab & $18.6^{a}$ & $1155.7^{a}$ & $323.58^{a}$ & $109^{a b}$ & $10^{a b c d}$ & 1109 a & 302.98 a & 2264.7 & 626.56 \\
\hline 8 & $63.3 \mathrm{efg}$ & $10.6 \mathrm{fg}$ & $563.6 \mathrm{~g}$ & $157.82 \mathrm{~g}$ & $98.6 \mathrm{bc}$ & $11^{a b c}$ & $591^{\mathrm{de}}$ & $157.77 \mathrm{de}$ & 1154.9 & 315.59 \\
\hline 9 & $61.6 \mathrm{fgh}$ & $8.3^{\mathrm{h}}$ & $397^{\mathrm{h}}$ & $87.34^{i}$ & $99 \mathrm{bc}$ & 9 bade & $535 \mathrm{e}$ & $160.94 \mathrm{de}$ & 932 & 248.28 \\
\hline 10 & 67 ef & 11.6 ef & $646.3^{f}$ & $180.97^{f}$ & $91^{\mathrm{dd}}$ & $6.6^{e}$ & $435.3^{f}$ & $101.7^{f}$ & 1081.6 & 282.67 \\
\hline 11 & $59.3 \mathrm{ghi}$ & $7.6^{h}$ & $380^{h}$ & $91.2^{i}$ & $81.3^{\text {def }}$ & 8.6 de & 593 de & $154.18^{\mathrm{de}}$ & 973 & 245.38 \\
\hline 12 & $54.3^{i}$ & $8.6 \mathrm{gh}$ & $430^{\mathrm{h}}$ & $94.6^{i}$ & $67^{f}$ & $8.3^{\mathrm{de}}$ & $641^{d}$ & $175.64^{d}$ & 1071 & 270.24 \\
\hline 13 & $73.1^{\mathrm{dd}}$ & 17.6 ab & 820 e & $246^{\mathrm{de}}$ & $83^{\mathrm{de}}$ & 9 bode & $823 \mathrm{bc}$ & $233.08^{b}$ & 1643 & 479.08 \\
\hline 14 & $56^{\mathrm{hi}}$ & 12 ef & $402^{\mathrm{h}}$ & $112.65^{\mathrm{h}}$ & $48 \mathrm{~g}$ & $13^{a}$ & $852^{b}$ & $233.81^{\mathrm{b}}$ & 1254 & 346.46 \\
\hline
\end{tabular}

Means within a column having the same letters are not significantly different according to Duncan's multiple range test.

Table 6. Growth traits of new geranium clones and the mother plant (no.14) during the second season

\begin{tabular}{|c|c|c|c|c|c|c|c|c|c|c|}
\hline \multicolumn{11}{|c|}{ Second season } \\
\hline \multirow{2}{*}{$\begin{array}{c}\text { Harvest } \\
\text { Clone } \\
\text { number }\end{array}$} & \multicolumn{4}{|c|}{ First cut } & \multicolumn{4}{|c|}{ Second cut } & \multicolumn{2}{|c|}{$\begin{array}{c}\text { Total fresh \&dry } \\
\text { weights of two cuts }\end{array}$} \\
\hline & $\begin{array}{l}\text { Plant } \\
\text { height } \\
\mathrm{cm} / \mathrm{p} .\end{array}$ & $\begin{array}{c}\text { Branches } \\
\text { no }\end{array}$ & $\begin{array}{l}\text { Fresh } \\
\text { weight } \\
\mathrm{gm} / \mathrm{p} .\end{array}$ & $\begin{array}{l}\text { Dry weight } \\
\text { gm / p. }\end{array}$ & $\begin{array}{l}\text { Plant } \\
\text { height } \\
\mathrm{cm} / \mathrm{p} .\end{array}$ & $\begin{array}{c}\text { Branches } \\
\text { no }\end{array}$ & $\begin{array}{l}\text { Fresh } \\
\text { weight } \\
\mathrm{gm} / \mathrm{p} .\end{array}$ & $\begin{array}{l}\text { Dry weight } \\
\mathrm{gm} / \mathrm{p} .\end{array}$ & $\begin{array}{l}\text { F.W. of the } \\
\text { two cuts } \\
\mathrm{gm} / \mathrm{p} \text {. }\end{array}$ & $\begin{array}{c}\text { D.W. of the } \\
\text { two cuts } \\
\mathrm{gm} / \mathrm{p} \text {. }\end{array}$ \\
\hline 1 & $69 c$ & $15^{b}$ & $616.3^{d}$ & 147.92 ef & 84 efg & 9c de & $591.3 \mathrm{ef}$ & 145.47 ef & 1207.6 & 293.39 \\
\hline 2 & $72.3^{c}$ & $12.3 \mathrm{~cd}$ & $953^{a b}$ & $266.84^{\mathrm{ab}}$ & $81.6 \mathrm{fg}$ & $10.6^{\mathrm{abcd}}$ & 581 ef & 158.27 def & 1534 & 425.11 \\
\hline 3 & $78.6^{b}$ & $14 \mathrm{bc}$ & $1010.3^{a}$ & $262.69 \mathrm{atc}$ & $84.3 \mathrm{efg}$ & $8^{\mathrm{de}}$ & $851^{\mathrm{bcd}}$ & $236.58^{b c}$ & 1861.3 & 499.27 \\
\hline 4 & $83.3^{a}$ & $15 \mathrm{~b}$ & $936.3^{a b}$ & 243.45 bc & $119.3^{a}$ & $12.6^{a}$ & 974 b & $261.99^{b}$ & 1910.3 & 505.44 \\
\hline 5 & $82^{a}$ & $11.6^{\mathrm{de}}$ & $835^{c}$ & $217.1^{d}$ & 86.6 efg & $10^{\text {abode }}$ & $745^{\mathrm{cde}}$ & $210.99 \mathrm{bcd}$ & 1580 & 428.09 \\
\hline 6 & $78.3^{b}$ & $14.3^{b}$ & $929.6 \mathrm{ab}$ & $241.71^{c d}$ & $78 \mathrm{~g}$ & $11.6^{a b c}$ & $635^{\text {def }}$ & $171.2^{\text {def }}$ & 1564.6 & 412.91 \\
\hline 7 & 84 a & 17 a & $1025^{a}$ & $287^{a}$ & $112^{\mathrm{ab}}$ & $11^{\mathrm{abc}}$ & $1332.3^{a}$ & $363.99 a$ & 2357.3 & 650.99 \\
\hline 8 & $64^{d}$ & $10 \mathrm{e}$ & $510.6 \mathrm{e}$ & $142.99 \mathrm{f}$ & $100.3^{\mathrm{cd}}$ & $12^{\mathrm{ab}}$ & $653^{c \text { def }}$ & $174.22^{\text {def }}$ & 1163.6 & 317.21 \\
\hline 9 & $58.6^{e}$ & $7.3^{f}$ & $348.3^{f}$ & $76.63^{h}$ & $93^{\mathrm{de}}$ & $9 \mathrm{cde}$ & $463^{f}$ & 139.27 ef & 811.3 & 215.9 \\
\hline 10 & $63.6 \mathrm{~d}$ & $10.3^{e}$ & $604.3^{d}$ & $169.21 \mathrm{e}$ & $93.3^{\mathrm{de}}$ & $7.3 \mathrm{e}$ & $504^{f}$ & $117.74 \mathrm{e}$ & 1108.3 & 286.95 \\
\hline 11 & $56.6^{e}$ & $7^{f}$ & $334^{f}$ & $80.16^{h}$ & 87 efg & 9.3 bode & 511.3 ef & $132.95 \mathrm{e}$ & 845.3 & 213.11 \\
\hline 12 & $51^{f}$ & $8^{f}$ & $491.6^{e}$ & $108.17 \mathrm{~g}$ & $78 \mathrm{~g}$ & 9.3 bode & $493.2^{f}$ & 135.13 ef & 984.8 & 243.3 \\
\hline 13 & $71.6^{c}$ & 17 a & $875.3 \mathrm{bc}$ & $262.6^{a b c}$ & 89.6 ef & 9.6 bode & $658^{\mathrm{cdef}}$ & 186.35 cde & 1533.3 & 448.95 \\
\hline 14 & $59 \mathrm{e}$ & $11^{\text {de }}$ & $439 \mathrm{e}$ & $122.92 \mathrm{fg}$ & 104 bc & $11^{a b c}$ & $872 b c$ & $239.28^{b c}$ & 1311 & 362.2 \\
\hline
\end{tabular}

Means within a column having the same letters are not significantly different according to Duncan's multiple range test. 


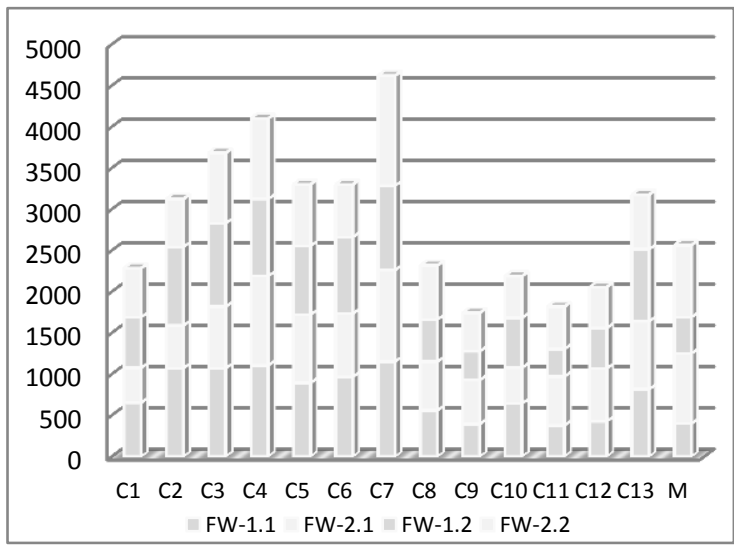

Fig. 2. Fresh weight (g/plant) of new geranium clones and the mother plant no. 14 during two seasons.

FW 1.1: Fresh weight of first cut first season

FW 2.1: Fresh weight of second cut first season

FW 1.2: Fresh weight of first cut second season

FW 2.2: Fresh weight of second cut second season

\section{Volatile oil and oil yield traits}

Data presented in Tables (7 \& 8) and Fig. (3) showed that clone no.7 produced the highest volatile oil content based on fresh weight basis in the first cut of the first season. However, some clones (no.3, 4, 6 and 13) as well as the mother plant (no.14) recorded the highest significant values for oil content based on fresh weight during the two seasons in comparison with the superior clone no.7. Clone no.7 recorded the highest traits values of all over the cloned production. As for oil yield traits, clone no.7 recorded the highest values for all cuts during the two seasons (Fig. 4) with high significant differences when compared with the other clones and with the mother plant. It achieved superior values among all over the cloned production as shown in Fig. (4), while the lowest values were recorded for clones no.9, 11 and 12.

Table 7. Volatile oil and oil yield traits of new geranium clones and the mother plant (no.14) in the first season.

\begin{tabular}{|c|c|c|c|c|c|c|c|}
\hline \multicolumn{8}{|c|}{ First season } \\
\hline Harvest & \multicolumn{3}{|c|}{ First cut } & \multicolumn{3}{|c|}{ Second cut } & \multirow[b]{2}{*}{$\begin{array}{c}\text { Oil yield of } \\
\text { two cuts } \\
\text { ml/plant }\end{array}$} \\
\hline $\begin{array}{c}\text { Clone } \\
\text { number }\end{array}$ & $\begin{array}{l}\text { vol.oil \% } \\
\text { based on } \\
\text { fresh } \\
\text { weight }\end{array}$ & $\begin{array}{l}\text { vol.oil \% } \\
\text { based on } \\
\text { dry weight }\end{array}$ & $\begin{array}{c}\text { Oil } \\
\text { yield } \\
\mathrm{ml} / \text { plant }\end{array}$ & $\begin{array}{c}\text { vol.oil \% } \\
\text { based on } \\
\text { fresh weight }\end{array}$ & $\begin{array}{l}\text { vol.oil\% } \\
\text { based on } \\
\text { dry weight }\end{array}$ & $\begin{array}{c}\text { Oil } \\
\text { Yield } \\
\mathrm{ml} / \text { plant }\end{array}$ & \\
\hline 1 & 0.207 ef & $0.861^{c d}$ & 1.36 ef & $0.16 \mathrm{gh}$ & $0.651^{d}$ & $0.675^{\mathrm{e}}$ & 2.035 \\
\hline 2 & $0.153 \mathrm{gh}$ & $0.548 \mathrm{~g}$ & $1.649 \mathrm{de}$ & $0.136^{\mathrm{h} \mathrm{i}}$ & $0.502 \mathrm{e}$ & $0.711^{e}$ & 2.36 \\
\hline 3 & $0.287 b c$ & $1.102^{a b}$ & $3.069 \mathrm{~b}$ & $0.24 \mathrm{ab}$ & $0.863 \mathrm{~b}$ & $1.803 \mathrm{bc}$ & 4.872 \\
\hline 4 & $0.25^{c d}$ & $0.962 b c$ & $2.769 b c$ & $0.176 \mathrm{fg}$ & $0.657^{d}$ & $1.919 b c$ & 4.688 \\
\hline 5 & $0.18 \mathrm{fg}$ & 0.692 efg & $1.621 \mathrm{de}$ & $0.206^{c}$ de & $0.73^{c d}$ & $1.708^{c}$ & 3.329 \\
\hline 6 & $0.25^{c d}$ & $0.961 b c$ & $2.434 \mathrm{c}$ & $0.213 \mathrm{bcde}$ & $0.791 \mathrm{bc}$ & $1.632^{\mathrm{c}}$ & 4.066 \\
\hline 7 & $0.35^{a}$ & $1.25^{a}$ & $4.044^{a}$ & $0.22 \mathrm{bcd}$ & $0.806 \mathrm{bc}$ & $2.436^{a}$ & 6.48 \\
\hline 8 & $0.213^{\mathrm{def}}$ & 0.761 def & $1.202^{f}$ & $0.193^{\mathrm{def}}$ & $0.725^{c d}$ & $1.139^{d}$ & 2.341 \\
\hline 9 & $0.123^{h}$ & $0.56 \mathrm{~g}$ & $0.493 \mathrm{~g}$ & $0.126^{i}$ & 0.421 ef & 0.679 e & 1.172 \\
\hline 10 & $0.173 \mathrm{fg}$ & $0.619 \mathrm{fg}$ & $1.117^{f}$ & $0.236^{a b}$ & $1.013^{a}$ & $1.031^{d}$ & 2.148 \\
\hline 11 & $0.14 \mathrm{gh}$ & $0.583 \mathrm{~g}$ & $0.534 \mathrm{~g}$ & 0.19 ef & $0.731^{\mathrm{cd}}$ & $1.125^{d}$ & 1.659 \\
\hline 12 & $0.123^{h}$ & $0.561 \mathrm{~g}$ & $0.526 \mathrm{~g}$ & $0.09 \mathrm{j}$ & $0.329^{f}$ & $0.576 \mathrm{e}$ & 1.102 \\
\hline 13 & $0.243^{d e}$ & $0.811^{\mathrm{cde}}$ & $1.996^{d}$ & $0.25^{a}$ & $0.883 \mathrm{~b}$ & $2.061 \mathrm{~b}$ & 4.057 \\
\hline 14 & $0.293 \mathrm{~b}$ & $1.048^{b}$ & $1.188^{f}$ & $0.223^{a b c}$ & $0.814 b c$ & $1.904 \mathrm{bc}$ & 3.092 \\
\hline
\end{tabular}

Means within a column having the same letters are not significantly different according to Duncan's multiple range test. 
Table 8. Volatile oil and oil yield traits of new geranium clones and the mother plant (no.14) in the second season.

\begin{tabular}{|c|c|c|c|c|c|c|c|}
\hline \multicolumn{8}{|c|}{ Second season } \\
\hline Harvest & \multicolumn{3}{|c|}{ First cut } & \multicolumn{3}{|c|}{ Second cut } & \\
\hline $\begin{array}{l}\text { Clone } \\
\text { number }\end{array}$ & $\begin{array}{l}\text { vol.oil \% } \\
\text { based on } \\
\text { fresh } \\
\text { weight }\end{array}$ & $\begin{array}{l}\text { vol.oil \% } \\
\text { based on } \\
\text { dry weight }\end{array}$ & $\begin{array}{l}\text { Oil yield } \\
\mathrm{ml} / \text { plant }\end{array}$ & $\begin{array}{l}\text { vol.oil \% } \\
\text { based on } \\
\text { fresh weight }\end{array}$ & $\begin{array}{l}\text { vol.oil \% } \\
\text { based on } \\
\text { dry weight }\end{array}$ & $\begin{array}{l}\text { Oil yield } \mathrm{ml} / \\
\text { plant }\end{array}$ & $\begin{array}{c}\text { Oil yield of } \\
\text { two cuts } \\
\mathrm{ml} / \mathrm{plant}\end{array}$ \\
\hline 1 & $0.233^{c}$ & $1.001^{\mathrm{ab}}$ & $1.442 \mathrm{~cd}$ & 0.15 ef & $0.61^{\mathrm{e}}$ & 0.88 efg & 2.322 \\
\hline 2 & $0.18^{d}$ & $0.643 \mathrm{de}$ & $1.715^{c}$ & $0.13 \mathrm{fg}$ & $0.477^{f}$ & $0.757 \mathrm{fg}$ & 2.472 \\
\hline 3 & $0.236^{c}$ & $0.91 b c$ & $2.405^{b}$ & $0.226 \mathrm{ab}$ & $0.815^{b}$ & $1.929 \mathrm{~b}$ & 4.334 \\
\hline 4 & $0.166 \mathrm{de}$ & $0.641 \mathrm{de}$ & $1.562 \mathrm{~cd}$ & $0.163 \mathrm{e}$ & $0.607 \mathrm{e}$ & $1.607 b c$ & 3.169 \\
\hline 5 & $0.183 \mathrm{~d}$ & $0.705 \mathrm{~d}$ & $1.528 \mathrm{~cd}$ & $0.186 \mathrm{~cd}$ & $0.659 \mathrm{de}$ & $1.394 \mathrm{~cd}$ & 2.922 \\
\hline 6 & $0.243 b c$ & $0.936 \mathrm{bc}$ & $2.259 \mathrm{~b}$ & $0.206 \mathrm{bc}$ & $0.767 \mathrm{bc}$ & $1.304 \mathrm{cde}$ & 3.563 \\
\hline 7 & $0.273 a b$ & $0.976 \mathrm{ab}$ & $2.813 \mathrm{a}$ & $0.23^{a b}$ & $0.842^{\mathrm{ab}}$ & $3.065 \mathrm{a}$ & 5.878 \\
\hline 8 & 0.143 ef & 0.512 ef & $0.742^{f}$ & $0.186 \mathrm{~cd}$ & $0.7 \mathrm{~cd}$ & $1.211 \mathrm{cde}$ & 1.953 \\
\hline 9 & $0.13^{f}$ & 0.591 def & $0.453^{f}$ & $0.116 \mathrm{gh}$ & $0.388 \mathrm{~g}$ & $0.545 \mathrm{~g}$ & 0.998 \\
\hline 10 & 0.133 ef & $0.476^{f}$ & 0.806 ef & $0.213^{b}$ & 0.913 a & $1.075^{\text {def }}$ & 1.881 \\
\hline 11 & $0.243 b c$ & $1.014 \mathrm{ab}$ & 0.814 ef & $0.17 \mathrm{de}$ & 0.654 de & 0.875 efg & 1.689 \\
\hline 12 & $0.243 b c$ & $1.106 \mathrm{a}$ & $1.195^{\mathrm{de}}$ & $0.1^{\mathrm{h}}$ & $0.365 \mathrm{~g}$ & $0.495 \mathrm{~g}$ & 1.69 \\
\hline 13 & $0.25 \mathrm{bc}$ & $0.833^{c}$ & $2.187^{b}$ & $0.24^{a}$ & $0.848 a b$ & $1.579 \mathrm{bc}$ & 3.766 \\
\hline 14 & 0.293 a & $1.048 \mathrm{ab}$ & $1.188^{d}$ & $0.23^{a b}$ & $0.838 a b$ & $2.001^{b}$ & 3.189 \\
\hline
\end{tabular}

Means within a column having the same letters are not significantly different according to Duncan's multiple range test

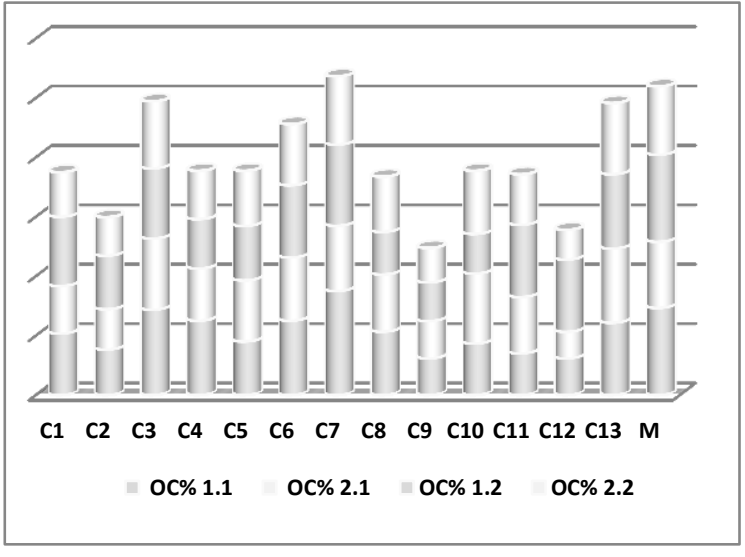

Fig. 3. Oil content percentage of new geranium clones and the mother plant (no. 14) during the two seasons. OC\% 1.1: Oil Content of first cut first season

OC\% 2.1: Oil Content of second cut first season

OC\% 1.2: Oil Content of first cut second season

OC\% 2.2: Oil Content of second cut second season

C1-C13: number of new clones $\quad \mathrm{M}$ : The mother plant

Concerning the oil content based on dry weight of the new clones, it was observed from data in Tables (7 \& 8) that clones no.7 and 10 recorded high significant values without significant differences compared with the mother plant in the two seasons followed by clones (no.3, 6 and 13), which also recorded significant content all over the cloned production in this trait.

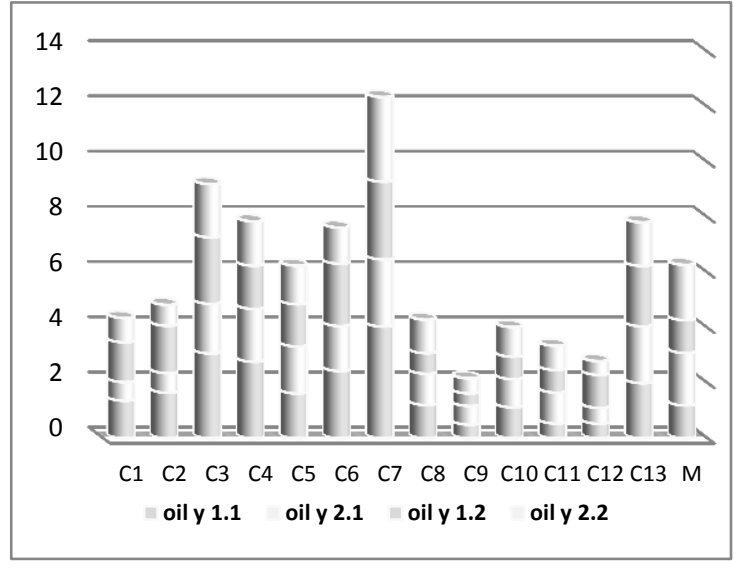

Fig. 4. Oil yield (ml/plant) trait of new geranium clones and the mother plant (no. 14) during the two seasons.

Oil y 1.1: oil yield of first cut first season

Oil y 2.1: oil yield of second cut first season

Oil y 1.2: oil yield of first cut second season

Oil y 2.2: oil yield of second cut second season

C1- C13: number of new clones M: The mother plant

\section{Oil composition of new geranium clones}

The gas liquid chromatograms (GLC) analysis as presented in Table (9) showed the essential oil constituents of the new clones of geranium at the time of the first cut. Ten components were identified represent $(83.24-95.94 \%)$ of the essential oil 
composition. The essential oil of the geranium clones contained 10 major constituents which were a-pinene, p-cymene, iso menthone, linalool, citronellyl formate, geranyl formate, citronellol, geraniol, eugenol and $\beta$ carophyllene. The relative proportion of these constituents in the oil of geranium clones basically determine its quality and were found to be in harmony with the standard specification of geranium essential oil, as described by Guenther (1961) and Harridy et al (1998). The quality of geranium oil is determined mainly by geraniol content, which varied between 26.5 $30.5 \%$ in the new clones instead of $33.22 \%$ for the mother plant. This range of geraniol content was found to be acceptable and indicate good quality of geranium clones essential oil. Also, citronellol contents showed variation from 17.25 to $28.5 \%$ instead of $21.6 \%$ for the mother plant. It was observed as shown in Fig. (5) that, however the mother plant had essential oil with high quality according to its high content of geraniol instead of citronellol, clone no.7 which recorded superior value in oil yield all over clones' production had acceptable balance between geraniol and citronellol for oil quality.

Table 9. Oil composition of new geranium clones and the mother plant (no.14) in the first cut first season

\begin{tabular}{|c|c|c|c|c|c|c|c|c|c|c|c|c|}
\hline $\begin{array}{c}\text { Compo- } \\
\text { nent } \\
\text { Clone no }\end{array}$ & $\begin{array}{c}\alpha- \\
\text { pinene }\end{array}$ & $\begin{array}{c}\text { P- } \\
\text { cymene }\end{array}$ & $\begin{array}{c}\text { Iso- } \\
\text { mentho- } \\
\text { ne }\end{array}$ & Linalool & $\begin{array}{l}\text { Citronellyl } \\
\text { formate }\end{array}$ & $\begin{array}{l}\text { Geranyl } \\
\text { formate }\end{array}$ & Citronellol & Geraniol & Eugenol & $\begin{array}{c}\beta- \\
\text { caryoph- } \\
\text { yllene } \\
\end{array}$ & Unknown & known \\
\hline 1 & 0.338 & 0.486 & 4.074 & 3.001 & 6.009 & 5.516 & 28.387 & 29.876 & 8.856 & 2.055 & 10.843 & 89.157 \\
\hline 2 & 0.277 & 0.751 & 4.135 & 4.237 & 6.818 & 6.442 & 26.049 & 29.753 & 11.668 & 2.666 & 6.532 & 93.468 \\
\hline 3 & 0.336 & 0.312 & 4.413 & 4.186 & 7.694 & 6.569 & 28.512 & 29.335 & 10.292 & 3.609 & 4.062 & 95.938 \\
\hline 4 & 0.318 & 0.291 & 4.268 & 4.031 & 7.347 & 6.321 & 27.694 & 29.246 & 11.126 & 2.008 & 6.676 & 93.324 \\
\hline 5 & 0.646 & 0.376 & 4.342 & 3.571 & 6.254 & 6.468 & 24.153 & 27.307 & 11.849 & 2.514 & 11.931 & 88.069 \\
\hline 6 & 0.464 & 0.547 & 4.276 & 3.939 & 7.713 & 5.229 & 23.333 & 30.532 & 11.959 & 2.848 & 8.455 & 91.545 \\
\hline 7 & 0.933 & 0.316 & 3.686 & 3.175 & 6.129 & 6.392 & 25.628 & 26.515 & 12.077 & 2.237 & 11.052 & 88.948 \\
\hline 8 & 1.066 & 0.403 & 4.252 & 4.65 & 6.319 & 6.25 & 20,287 & 29.077 & 14.194 & 2.381 & 10.902 & 89.098 \\
\hline 9 & - & 0.959 & 2.773 & 2.417 & 8.038 & 8.014 & 19.542 & 28.758 & 11.987 & 1.322 & 15.435 & 84.565 \\
\hline 10 & 0.287 & 0.891 & 4.358 & 3.969 & 6.897 & 6.392 & 26.395 & 28.093 & 10.075 & 2.998 & 7.824 & 92.176 \\
\hline 11 & 0.359 & 0.408 & 4.542 & 3.649 & 6.324 & 6.365 & 25.317 & 29.471 & 11.081 & 2.598 & 9.345 & 90.655 \\
\hline 12 & - & 0.553 & 2.431 & 2.352 & 6.441 & 6.559 & 17.25 & 27.041 & 14.769 & 5.386 & 16.76 & 83.24 \\
\hline 13 & - & 0.438 & 3.444 & 2.869 & 6.254 & 6.093 & 25.105 & 30.243 & 9.523 & 2.45 & 12.41 & 87.59 \\
\hline 14 & - & 0.373 & 3.454 & 3.349 & 6.036 & 7.134 & 21.536 & 33.216 & 8.85 & 2.437 & 13.112 & 86.888 \\
\hline
\end{tabular}

C G

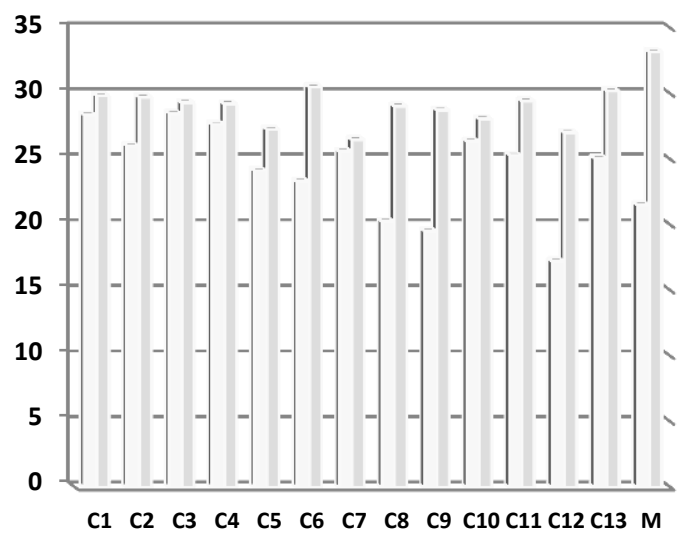

Fig. 5. Geraniol \% and citroneloll \% in new geranium clones and the mother plant no. 14 in the first cut first season

$\mathrm{G}$ : Geraniol C: Citroneloll

C1- C13: number of new clones M: Mother plant

\section{Genetic variation based on SRAP-PCR tech- nique}

The SRAP analysis of the DNAs of new geranium clones and their mother plant El Qanater El khayria cv. 8 using 16 combinations of SRAP primers (me1, me2, me3 and me4 with em1, em2, em3 and em4) (Table 2) as forward and reverse primers were carried out in two samples to test the genetic variations among the new clones as compared to the mother plant. The results presented in Table (10) indicated that only five pairs of SRAP primer combinations (me4 em1, me1 em3, me2 em3, me2 em4 and me3 em4) showed polymorphism between the two selected samples. The me2 em4 primer pair was found to be more informative, which showed highly polymorphism, while the other primer combinations were not effective which showed the same pattern with the two tested samples. 
Table 10. Results of SRAP primer combinations

\begin{tabular}{|c|c|c|c|c|}
\hline $\begin{array}{c}\text { Primer } \\
\text { combination }\end{array}$ & me1 & me2 & me3 & me4 \\
\hline em1 & - & - & - & + \\
em2 & - & - & - & - \\
em3 & + & + & - & - \\
em4 & - & +++ & + & - \\
\hline
\end{tabular}

me1 to me4: SRAP primers served as forward primer em1 to em4 SRAP primers served as reverse primer + : polymorphic - : non polymorphic

+++ : polymorphic \& more informative.

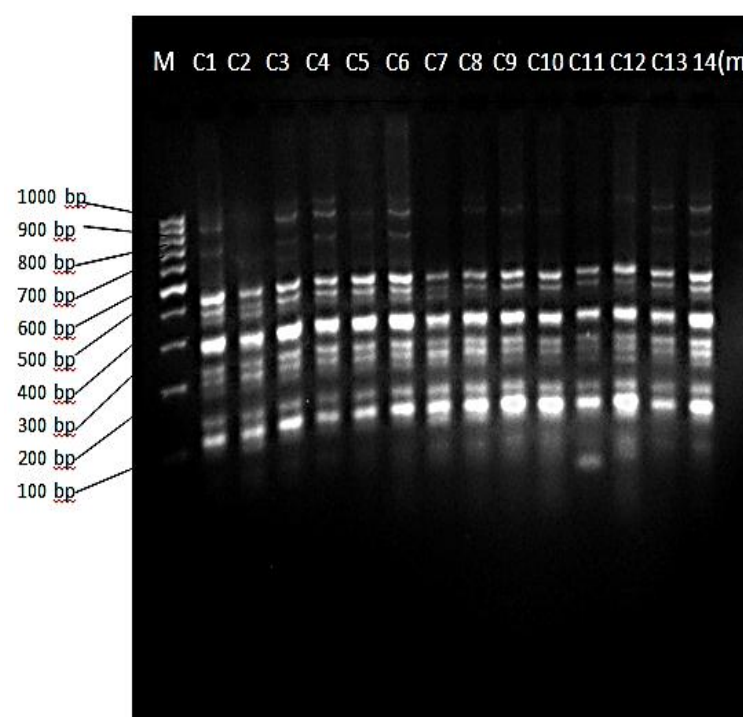

Fig. 6. The SRAP profile detecting variation among the new clones and their mother plant by (me2 em4) primer pair C1- C13: number of new clones $14(\mathrm{~m})$ : the mother plant

M: 100bp Molecular marker

The me2 em4 primer pair was carried out on the DNAs of the new clones to ascertain genetic difference among them with relative to the mother plant. As seen in Fig. (6) and Table (11), the used SRAP primer could differentiated among the clones and the mother plant, Fourteen fragments at molecular sizes of $1289.7 \mathrm{bp}$ to $97.6 \mathrm{bp}$ were seen on the clones and their mother plant profile with a $42.86 \%$ of polymorphism. Eight monomorphic fragments were present in all clones and their mother plant.
The polymorphic fragments at molecular sizes of $1289.7,111.24,894.3$ and 471.7 bp appeared in some clones and the mother plant and absent in the others. Other fragment at molecular size of 700.7 bp was present in clones no. 2 and no. 3 and absent in the others and in the mother plant. While the unique fragment presented at molecular size of 97.6 bp was observed in clone no.11 which disappeared in the mother plant and the other clones. A unique profile was present in clone no.7, which all fragments at molecular sizes from 1289.7 to 700.7 bp were absent. This unique profile could differentiate this clone among the other clones and the mother plant. This result could be associated with the yield and oil traits which demonstrated that this clone was superior in these traits.

The SRAP analysis of DNAs ascertained the genetic variations among somaclones and the mother plant. It was demonstrated that, the similarity values of these new clones varied from $66.7 \%$ to $100 \%$ comparing to their mother plant. The dendrogram tree separated the 13 clones with their mother plant into two major clusters as shown in Fig. (7). However, within the first cluster, the mother plant (no.14) and the closet related clones no. 6 and 13 with a $100 \%$ of similarity value were collected together. The no.12 clone was more related to clones no. 6 and 13 and their mother plant and clone no. 4 was more related to clone no.3. Within the second cluster, clones no.5, 9, 10 and 11 were collected together in the first sub-cluster, while clones no.2, 7 and 8 were collected together in the second sub-cluster. While clone no. 1 was the most distance one compared with the other new clones and their mother plant.

The results of dendrogram tree confirmed, by the yield and oil traits of the new clones, that the genetic variations among the new clones and their mother plant were detected and proved that the Egyptian geranium cultivar El Qunater El Khayria cv.8 was somaclonal mutated as shown in all studied traits.

Our results were confirmed by Tembe and Deodhar (2010) who differentiated and detected the genetic variation among geranium cultivars (Reunion, Bourbon and Egyptian of Pelargonium graveolens L'Herit, Ait.) using RAPD technique. Moreover, Gupta et al (2002) detected the genetic variation among in-vitro somaclones Pelargonium graveolens L'Herit, Ait. using RAPD technique and revealed a "B22" somaclone which was high yielded in herb and essential oil. 
Table 11. SRAP-PCR fragments of the me2 em4 primer pair with the new clones and the mother plant

\begin{tabular}{|c|c|c|c|c|c|c|c|c|c|c|c|c|c|c|c|}
\hline MS & $\mathbf{c}$ & $\mathbf{c 2}$ & $\mathbf{c 3}$ & $\mathbf{c 4}$ & $\mathbf{c 5}$ & $\mathbf{c 6}$ & $\mathbf{c 7}$ & $\mathbf{c 8}$ & $\mathbf{c 9}$ & $\mathbf{c 1 0}$ & $\mathbf{c 1 1}$ & $\mathbf{c 1 2}$ & $\mathbf{c 1 3}$ & $\mathbf{c 1 4}$ & $\begin{array}{c}\text { Polymor- } \\
\text { phism }\end{array}$ \\
\hline $\mathbf{1 2 8 9 . 7}$ & 0 & 0 & 1 & 1 & 0 & 1 & 0 & 0 & 0 & 0 & 0 & 1 & 1 & 1 & Polymorphic \\
$\mathbf{1 1 1 2 . 4}$ & 1 & 1 & 1 & 1 & 1 & 1 & 0 & 1 & 1 & 1 & 1 & 1 & 1 & 1 & Polymorphic \\
$\mathbf{8 9 4 . 3}$ & 1 & 0 & 1 & 1 & 1 & 1 & 0 & 0 & 0 & 0 & 0 & 0 & 1 & 1 & Polymorphic \\
$\mathbf{7 0 0 . 7}$ & 0 & 1 & 1 & 0 & 0 & 0 & 0 & 0 & 0 & 0 & 0 & 0 & 0 & 0 & Polymorphic \\
$\mathbf{5 8 6 . 7}$ & 1 & 1 & 1 & 1 & 1 & 1 & 1 & 1 & 1 & 1 & 1 & 1 & 1 & 1 & Monomorphic \\
$\mathbf{5 1 1 . 7}$ & 1 & 1 & 1 & 1 & 1 & 1 & 1 & 1 & 1 & 1 & 1 & 1 & 1 & 1 & Monomorphic \\
$\mathbf{4 7 1 . 7}$ & 1 & 1 & 0 & 0 & 0 & 1 & 1 & 1 & 0 & 0 & 0 & 1 & 1 & 1 & Polymorphic \\
$\mathbf{3 8 4 . 9}$ & 1 & 1 & 1 & 1 & 1 & 1 & 1 & 1 & 1 & 1 & 1 & 1 & 1 & 1 & Monomorphic \\
$\mathbf{3 0 6 . 0}$ & 1 & 1 & 1 & 1 & 1 & 1 & 1 & 1 & 1 & 1 & 1 & 1 & 1 & 1 & Monomorphic \\
$\mathbf{2 7 3 . 9}$ & 1 & 1 & 1 & 1 & 1 & 1 & 1 & 1 & 1 & 1 & 1 & 1 & 1 & 1 & Monomorphic \\
$\mathbf{2 5 2 . 5}$ & 1 & 1 & 1 & 1 & 1 & 1 & 1 & 1 & 1 & 1 & 1 & 1 & 1 & 1 & Monomorphic \\
$\mathbf{1 9 7 . 8}$ & 1 & 1 & 1 & 1 & 1 & 1 & 1 & 1 & 1 & 1 & 1 & 1 & 1 & 1 & Monomorphic \\
$\mathbf{1 6 8 . 1}$ & 1 & 1 & 1 & 1 & 1 & 1 & 1 & 1 & 1 & 1 & 1 & 1 & 1 & 1 & Monomorphic \\
$\mathbf{0 9 7 . 6}$ & 0 & 0 & 0 & 0 & 0 & 0 & 0 & 0 & 0 & 0 & 1 & 0 & 0 & 0 & Unique \\
TO- & $\mathbf{1}$ & $\mathbf{1 1}$ & $\mathbf{1 2}$ & $\mathbf{1 1}$ & $\mathbf{1 0}$ & $\mathbf{1 2}$ & $\mathbf{9}$ & $\mathbf{1 0}$ & $\mathbf{9}$ & $\mathbf{9}$ & $\mathbf{1 0}$ & $\mathbf{1 1}$ & $\mathbf{1 2}$ & $\mathbf{1 2}$ & \\
TAL & $\mathbf{1}$ & & & & & & & & & & & & & & \\
\hline
\end{tabular}

C1 to C13: new clones of geranium C14: the mother plant

0 : absence of SRAP fragment $\quad 1$ : presence of SRAP fragment $\quad$ MS: molecular size of SRAP fragments

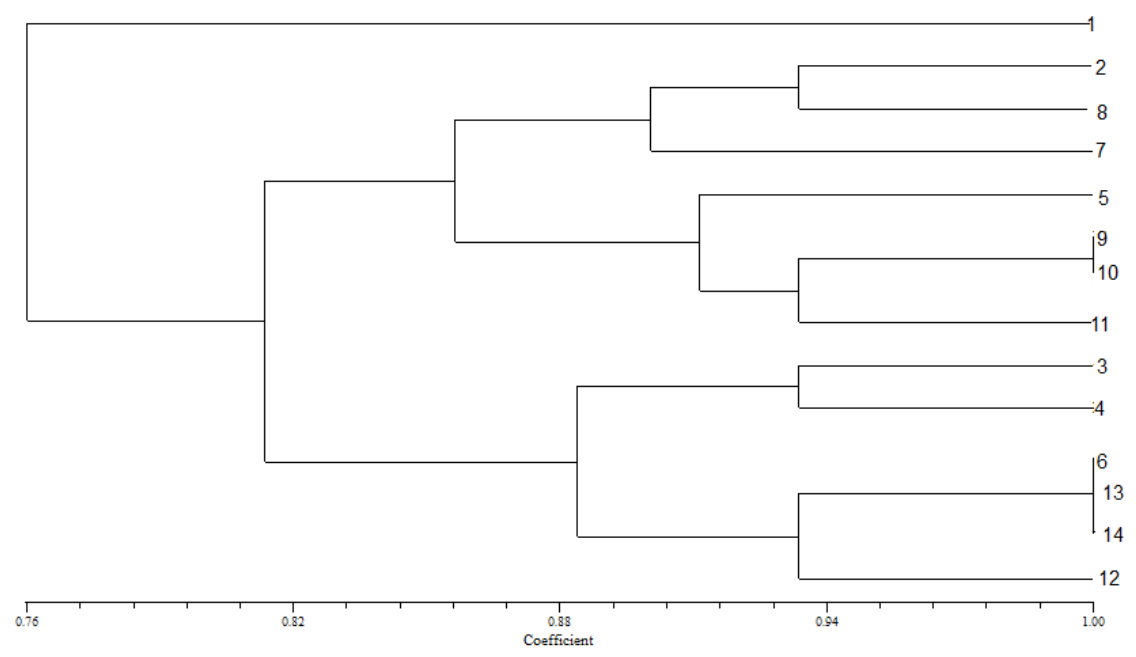

Fig. 7..Dendrogram tree demonstrated the relationships among the somaclones and their mother plant C1- C13: number of new clones 14: The mother plant

It was concluded that in vitro somaclonal variation technique lead to produce new clones which were genetically and morphologically improved than geranium, Pelargonium graveolens L'Hérit cultivar. No.7 clone is a superior clone in yield and essential oil traits which could be recommended for mass production, after two seasonal evaluations. Somaclonal variation is an efficient tool for improving vegetative regenerated plants.

\section{REFERENCES}

Amar, M.H., Biswas M.K., Zhang Z and Guo WK. 2011. Exploitation of SSR, SRAP and CAPS-SNP markers for genetic diversity of citrus germplasm collection. Scientia Horticulturae 128, 220-227.

Arab Republic of Egypt, Ministry of Agriculture. and Land Reclamation Economic Affairs, 
Sector, 2016, Bulletin of Agriculture Statistics, Part 1, Winter Crops, 2014- 2015, 92 p. Cairo, Egypt.

British Pharmacopoeia 1963. The Pharmaceutical Press Bloomsburg, 17, 112-125, Square. W.Cl. London, UK.

Brown, J.T. and Charlwood, B.V.. 1986. The control of callus formation and differentiation in scented pelargoniums. J. Plant Physiol. 123, 409-417.

Budak, H., Shearman R.C., Parmaksiz I. and Dweikat I. 2004. Comparative analysis of seeded and vegetative biotype buffalograsses based on phylogenetic relationship using ISSRs, SSRs, RAPDs, and SRAPS. Theor Appl Genet, 109, 280-288.

Dunbar, R.R. 1997. In: Advances in Agronomy. Tissue culture induced variations and crop improvement, Academic Press, New York, USA, Ch. 58, pp. 201-240.

Dunbar, K.B. and Stephens, C.T. 1989. Shoot regeneration of hybrid seed of geranium (Pelargonium $X$ hortorum) and regal geranium (Pelargonium $X$ domesticum) from primary callus culture. Plant Cell Tiss. Org. Cult. 19, 13-21.

Duncan, D.B. 1995. Multiple Range and Multiple "F" test Biometrics, 11, 1-42.

Egyptian Pharmacopoeia. 2005. The English Text of Arab Republic of Egypt, $4^{\text {th }}$ ed., Central Adminstration and Pharmaceutical Affairs (CAPA). Ministry of Health and Population: Cairo, Egypt, pp. 31-33.

Evans, D.A. and W.R. Sharp. 1986. Applications of Somaclonal Variation_Bio/Technology, 4(6), 528- 532.

Evans, David A. 1989. Somaclonal variation-Genetic basis and breeding applications. Trends Genet. 5, 46-50.

Gauri, S., S. Banerjee, L. Rahman, G.R. Mallavarapu, S. Sharma, Sushil-Kumar and S. Kumar. 2000. An effentiant in vitro procedure for micropropagation and generation of somaclones of rose scented Pelargonium. Plant Science Limerick.155(2), 133-140.

Guenther, E. 1961. The Essential Oils. D. Van Nostrand Company, Inc. Princeton, New Jersey, New York, USA, 1, 3-4.

Gulati, B.C. 1960. Cultivation of geranium. Ind. Oil Soap J. 26(2), 35-43.

Gupta, Ritika, S. Banerjee, G.R. Mallavarapu, S. Sharma, S.P.S Khanuja, A.K. Shasany and Sushil Kumar1. 2002. Development of a superior somaclone of Rose-scented geranium and a protocol for inducing variants. HortScience. 37(4), 632-636.

Harridy, I.M.A., El-Zahwey, A.M.H., Soliman, S.G.I. and El-Taweel, S.M.I..1998. Geranium cultivars with a high herb and oil productivity. J. Agric. Sci., Mansoura Univ., 23(6), 26872697.

Jalali-Heravi, M., Zekavat, B. and Sereshti, H., 2006. Characterization of essential oil components of Iranian geranium oil using gas chromatography-mass spectrometry combined with chemometric resolution techniques. J. Chromatoger. A 1114, 154-163.

Korir, Nicholas Kibet, Jian Han, Lingfei Shangguan, Chen Wang, Emrul Kayesh, Yanyi Zhang, and Jinggui Fang. 2013. Plant variety and cultivar identification: advances and prospects. Critical Reviews in Biotechnology, 33(2), 111-125.

Kubba, A.S., Tilney-Basset, R.A.E. 1981. Genetical studies of embryo survival and embryo breakdown in Pelargonium x hortorum Bailey. Euphytica. 30, 881-887.

Lakshmana Rao, P.V. 1994. In vitro regeneration of scented-leaved geranium Pelargonium graveolens. Plant Sci., 98, 193-198.

Lawrence, B.M. 1984. Progress in essential oils Pref. and Falv. 9, 987-995.

Li, G. and Quiros, C.F. 2001. Sequence-related amplified polymorphism (SRAP), a new marker system based on a simple PCR reaction: its application to mapping and gene tagging in Brassica. Theor Appl Genet 103, 455-461.

Lin, Z.X., Zhang, X.L., Nie Y.C., He D.H. and Wu M.Q. 2003. Construction of a genetic linkage map for cotton based on SRAP. Chin. Sci. Bull 48, 2063-2067.

Liu, L.W., Zhao L.P., Gong Y.Q., Wang M.X., Chen L.M., Yang J.L., Wang Y., Yu F-M. and Wang L-Z. 2008. DNA fingerprinting and genetic diversity analysis of late-bolting radish cultivars with RAPD, ISSR and SRAP markers. Scientia Horticulturae 116, 240-247.

Murashige, T. and F. skoog. 1962. A revised medium for rapid growth and bioassays with tobacco tissue culture. Physiol. Plant. 15, 473497.

Narayana, M.R., Prakasa Rao, E.V.S., Rao B.R.R., Sastry, K.P. 1986. Geranium cultivation in India: Potentials and Prospects, Pafai J. 8, 25-30

Qureshi, J.A. and P.K. Saxena. 1992. Adventitious shoot induction and somatic embryogenesis with intact seedlings of several hybrid seed 
geranium varieties (Pelargonium $X$ hortorum Bailey). Plant Cell Rep., 11, 443-448.

Rajeswara, Rao, Prakasa Rao, B.R. and Naryana M.R.. 1989. Rose geranium: An economical crop in the south Indian Plains. Ind. Hortic. 36(2), 14-17.

Saghai-Maroof, M.A., Soliman K.M., Jorgensen R. Am. and Allard R.W.L.1984.Ribosomal DNA spacer-length polymorphisms in barley: Mendelian inheritance, chromosomal location and population dynamics. Proc. Nat. Academy of Science. 81(24), 8014-8018.

Saxena, G., S. Banerjee, L. Rahman, G.R. Mallavarapu, S. Sharma, and S. Kumar. 2000 An efficient in vitro procedure for micropropagation and generation of somaclones of rosescented Pelargonium. Plant Sci. 155, 133-140.

Skirvin, R.M. and Janick J.. 1976a. Tissue culture. Induce variation in scented Pelargonium spp. J. Am. Soc. Hort. Sci. 101, 281-290.

Skirvin, R.M. and Janick J. 1976b. "Velvet rose" Pelargonium: A scented geranium Hort. Science.11, 61-62.

Snedecor, G.W. 1980. Statistical Methods. $5^{\text {th }}$ Ed. lowa State College Press, Ames. Iowa, U.S. A.

Teisseire, P., 1987. Industerial quality control of essential oils by capillary GC. In: Sandra P. and Bicchi C. (Ed.), Capillary Gas Chromatography in Essential Oil Analysis. Huethig, Heidelberg, pp. 215-258.
Tembe, Rashmi P. and Manjushari A. Deodhar. 2010. Chemical and Molecular fingerprinting of different Pelargonium graveolens L'Herit. Viz., Reunion, Bourbon and Egyptian. Biotechnology. 9(4), 485-491.

Uzun, A., Yesiloglu T., Aka-Kacar Y., Tuzcu 0. and Gulsen O. 2009. Genetic diversity and relationships within citrus and related genera based on sequence related amplified polymorphism markers (SRAPs). Sci Hortic 121, 306312.

Veilleux, R.E. and Johnson, A.A.T. 1998. Somaclonal variations: Molecular analysis, transformation interaction and utilization. In: Janick J. (ed.). Plant Breeding Rev., 16, 229268.

Weiss, E.A. 1997. Essential Oil Crops. CAB. International. Geraniaceae. 3, 24-58.

Zaefizadeh, M. and Goliev R. 2009. Diversity and relationships among durum wheat landraces (subconvars) by SRAP and phenotypic marker polymorphism. Res. Biol. Sci., 4, 960-966.

Zhang, Y.X., Sun J., Zhang X.R., Wang L.H. and Che Z. 2011. Analysis on genetic diversity and genetic basis of the main sesame cultivars released in China. Agri. Sci. China, 10, 509518.

Zhao, W., Fang R., Pan Y., Yang Y., Chung J.W., Chung I.M. and Park Y.J. 2009. Analysis of genetic relationships of mulberry (Morus spp. L.) germplasm using sequence-related amplified polymorphism (SRAP) markers. Afr. J. Biotechnol., 8, 2604-2610. 


\section{Pelargonium graveolens L’Hérit. Ait. إنتاج تباينات جسدية معمليا لنبات العتر}

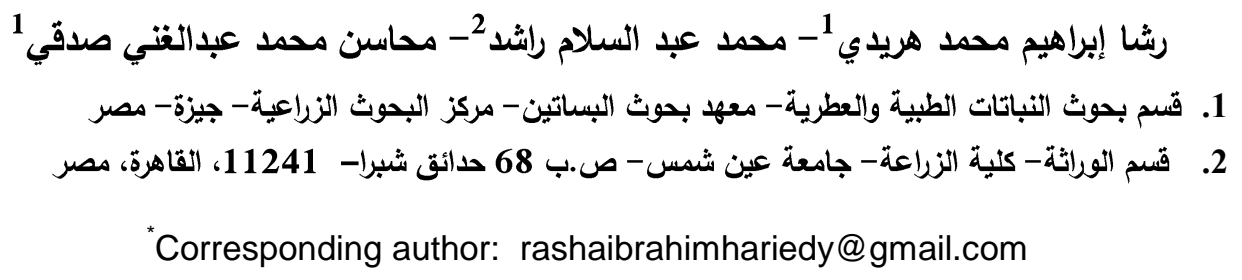

Received 14 October, 2018,

Accepted 24 October, 2018

وقد تفوقت السلالة الجديدة رقم 7 في محصول

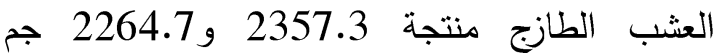

عشب/النبات ومحصول الزيت 2.436 و 2357.065 ملايتز / النبات في كل من الموسمين الأول والثاني علي الني

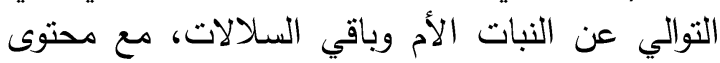
مقبول من مكونات الزيت جيرانيول 26.52 الاتل وسيترونيللول 25.63\% كمقياس لجودة الزيت الطيار . وتم إختبار الاختلافات الوراثية للسلالات الجديدة

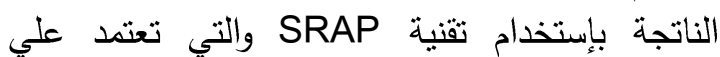

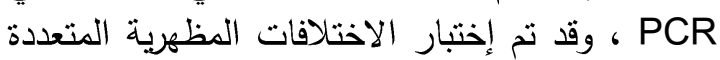
بإستخدام 16 زوج من بادئات SRAP في نركيبات مختلفة.

وقد تأكدت الاختلافات الوراثية بين السلالات

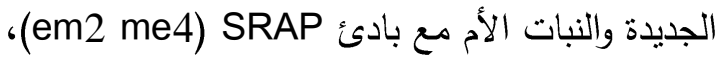
وقد إنفردت السلالة رقم7 بشكل مظهري مميز بإستخدام تحليل ال SRAP عن باقي السلالات.

إن وجود الاختلافات الوراثية بين السلالات الجات الجديدة

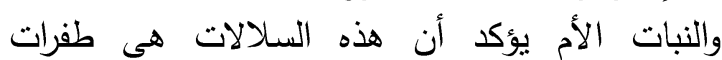
خضرية ترجع للتغيرات الجسدية ، وأن السلالة التهات القناطر

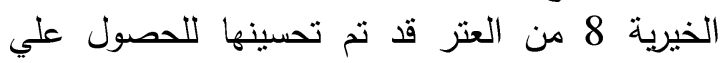

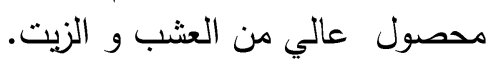

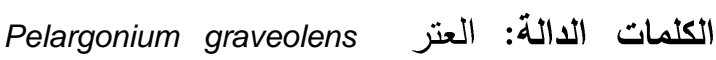
SRAP L'Hérit. Ait.
يعتبر التباين الجسمي للكالس في المعمل أحد اكثر

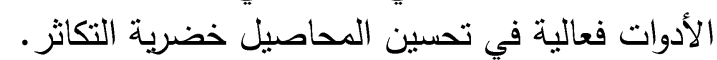

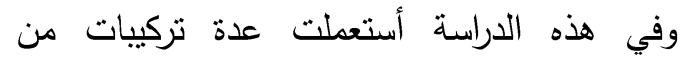

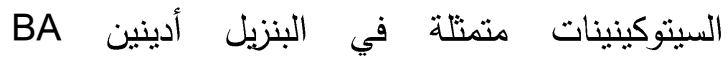

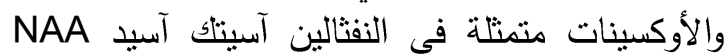

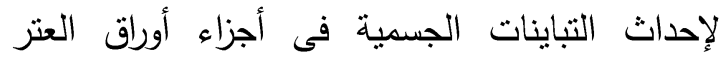
المصري السلالة " القناطر الخيرية 8" . ل التان

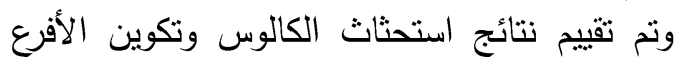

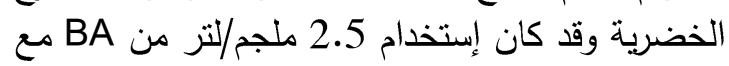
0.5ملجم/لتر من هو التركيب المثالي في هذا الثشأن.

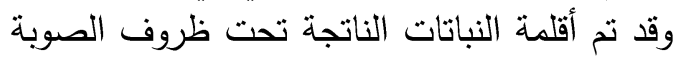
الزجاجية وترواحت نسبة النباتات الحية من 80\%ة 90 حيث تم نقلها إلي الحقل المفتوح. تم تقييم 13 سلالة خضرية جديدة من حيث صفات التهات النمو الخضرية وتحليل الزيت العطري بالمقارنة بالنبات

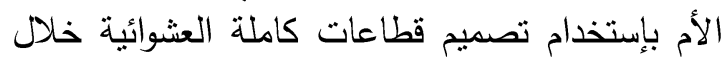

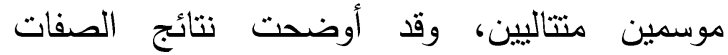
الخضرية المورفولوجية ولئين ومحصول الزيت الطيار

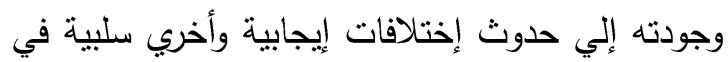
بعض الصفات بالمقارنة بالنبات الأم. 